\title{
LA VISUALIZACIÓN DE LA JUSTICIA EN EL ANTIGUO RÉGIMEN. EL EJEMPLO DE LA CHANCILIERIAA DE GRANADA
}

\author{
por \\ INÉS GÓMEZ GONZÁLEZ \\ Universidad de Granada.
}

RESUMEN: Si importante es tener el poder, transmitirlo es clave. $Y$ en este punto juegan un papel fundamental los poderes intermedios. En el presente articulo se intenta mostrar cómo una institución de este tipo, la Chancilleria de Granada, partiendo del impresionante prestigio que le da la Corona, manifiesta al pueblo no sólo su poder, sino el de la Monarquía. Para ello, utiliza todos los recursos a su alcance: el programa iconográfico del edificio, la decoración de sus salas, las apariciones publicas del tribunal como Real Acuerdo y el tratamiento dado a su presidente.

Palabras ClAVE: Instituciones, Administración, Chancilleria, Edad Moderna, España.

ABSTRACT: However important baving power may be, transmitting it is essential, and intermediate powers play a fundamental role in this. This article explains bow an institution sucb as the Cbancellery of Granada, starting from the great prestige given to it by the Crown, shows the people not only its own power but the monarchy's power. All the resources witbin its reach are used to that purpose: the iconograpbic programme of the building, the decoration of the rooms, the public appearances of the judges actording to a Royal Agrement and the form of addressing the presiding judge.

KEY WORDS: Institutions, Administration, Chancillery, Spain.

La justicia en el Antiguo Régimen es consubstancial a la Corona, hasta tal punto que, como dice uno de los máximos teorizadores del poder en el Seiscientos, «faltando ésta, falta el orden de república y cesa el oficio de rey»). ${ }^{1}$ Por distintas razones, en las que no podemos entrar aquí, el rey delega la administración de la misma en ciertas instituciones, que por ello participan de alguna manera de la majestad y de su imagen simbólica.

1 SANEDRA FAJARDO, D., Idea de un principe palitico-cristiano representada en cient empresas, Madrid, Espasa-Calpe, 1958, vol. I, pp., 193-194.

IHipania, LVIII/2, núm 199 (1998) 559-574 
La historia del «imaginatio monárquico» es hoy bien conocida. La utilización de mitos, ritos, imágenes y símbolos como forma de legitimación es un hecho ampliamente estudiado por historiadores, sociólogos y antropólogos desde que clásicos como M. Weber, M. Bloch o E. Kantorowicz resaltaran su importancia. Este fenómeno, que se rastrea desde la Antigüedad hasta nuestros días $^{2}$, adquiere un valor extraordinario en el Antiguo Régimen, cuando el lenguaje simbólico se convierte en un recurso imprescindible para crear una imagen idealizada del monarca que ayude a consolidar el proceso de absolutización y divinización de su poder.

Transmitit esta imagen es fundamental. De ahí que se utilicen vías muy diversas para hacerlo ${ }^{3}$. Son claves la etiqueta que rodea la vida del monarca en la Corte ${ }^{4}$, el ceremonial que preside cualquier aparición pública del rey ${ }^{5}, \circ$ los ritos que acompañan momentos tan significativos como su coronación o muerte 6 . Estos símbolos, y otros muchos, que contribuyen a la legitimación del poder, no solo se divulgan en presencia del soberano. Pueden difundirse, y a

2 Magistralmente lo expone GARCIA-PELAYO, M., en «Mito y actitud mitica en el campo políticon, en Los mitos políticos, Madrid, Alianza, 1981, págs. 11-37. Sobre esta cuestión véanse también RouX, J. P., Le roi. Mythes et symboles, Paris, Fayard, 1995, quien ha estudiado los mitos y los símbolos que todean la figura del rey en distintos tiempos y culturas, y PITI-RIVERS, J. y PERISTINNY, J. G. (eds), Honor y Gracia, Madrid, Alianza, 1992, en el que desde muy diversas perspectivas se subraya la fuerza del rito para establecer la legitimidad.

3 Como obras de carácter general pueden consultarse DUFOURNEY, J., FloRATO, A. et REDONDO, A., Le pouvoir monarchique et ses supports ideologiques aux XIVe-XVIIe siècles, Paris, Publications de la Sorbonne Nouvelle, 1990, AA.VV., La Monarcbie Absolutiste et lthistoire en France. Theories du pouvoir, propagandes monarcbiques et mythologies nationales, Paris, Presses de l'Université de Paris-Sorbonne, 1987, y, centrado en España, LISÓN TOLOSANA, C., La imagen del rey. Monarquía, realeza y poder en la Casa de Austria, Madrid, Austral, Espasa Calpe, 1991.

4 Siguiendo a N. ELIAS, quien en La sociedad cortesana, Madrid, Fondo de Cultura Económica, 1993, destaca la importancia de la función simbólica de la etiqueta y cómo se manifiesta a través de ella el poder de Luis XIV, muchos estudiosos han incorporado esta perspectiva al tratar el tema. Para una visión historiográfica de la cuestión, MERLIN, P., «Il tema de la Corte nella storiografia italiana ed europeas», Studi Storici, 1986, págs. 203-244. En esta línea es interesante el artículo de HESPANYIA, A. M., «La Corte», en La gracia del derecho. Economía de la culura en la época moderna, Madrid, Centro de Estudios Consritucionales, 1993, págs. 177-202. Sobre la misma cuestión en España caben destacarse los trabajos de MARTÍNEZ MILLÁN, J. (dir.), La corte de Felipe II, Madrid, Alianza, 1994, BOUZA, F, Locos, enanos y bombres de placer en la corte de los Austrias, Madrid, Temas de hoy, 1996, EllioTT, J. H., España y su mundo. 1500-1700, Madrid, Alianza Editorial, 1990 (en particular los capitulos 7 y 8), y GÓMEZ-CENTURIÓN GIMÉNEZ, C., «Etiqueta y ceremonial palatino durante el reinado de Felipe V: El reglamento de entradas de 1709 y el acceso a la persona del Reys, Hispania, n. ${ }^{\circ} 194,1996$, págs. 965-1005.

5 Acerca del tema, aunque centrado en la Edad Media, NIETO SORIA, J. M., Ceremonias de la realeza. Propaganda y legitimación en la Castilla Trastamara, Madrid, Nerea, 1993.

6 Sobre el papel de estos ritos como medios de legitimar la sucesión sigue siendo fundamental la obra de KANTOROWICZ, Los dos cuerpos de/ rey. Un estudio de teología politica medieval, Madrid, Alianza, 1985. Para el caso español pueden verse VARELA, J., La muerte del rey. El ceremonial funerario de la monarquía española (1500-1885), Madrid, Tumer, 1990, y MARTíN, J. L., «El rey ha muerto. iViva el reyb), Hispania, n." 177, 1991, págs. 5-39.

Hipquia, LVIII/2, num 199 (1998) 559-574 
veces con mucha fuerza, a través del arte ${ }^{7}$, la literatura ${ }^{8}$, las fiestas ${ }^{9} \mathrm{y}$, por supuesto, las instituciones.

En estas páginas voy a intentar mostrar cómo una institución concreta, la Chancillería de Granada, apoyándose en el prestigio que en parte le da la Corona y apropiándose de su lenguaje y sus símbolos, transmite esta imagen arquetípica de la monarquía y de su función más emblemática, la justicia ${ }^{10}$.

$\mathrm{La}$ Corona otorga desde el principio a las Chancillerías el mismo tratamiento que originariamente tenían los monarcas, el de muy upoderoso señor y alteza) ${ }^{11}$. Es cierto que a partir de Carlos V -en algunos casos los Reyes

7 Entre los trabajos que inciden en la importancia del arte como instrumento de propaganda política hay que destacar el estudio sobre el Retiro de BROWN y ELLIOTT, Un palacio para el rey. El buen retiro y la corte de Felipe IV, Madrid, Alianza, 1981, y la obra de J. GÁLLEGO, Visión y simbolos de la pintura española, Madrid, Cátedra, 1991. Las investigaciones sobre el arte cortesano en España durante el Antiguo Régimen han puesto de manifiesto su evolución en función de las necesidades del poder. Para el siglo XVI son útiles las obras de DOMínGUEZ CASAS, Arte y etiqueta de los Reyes Catblicos. Artistar, residencias, jardines y bosques, Madrid, Alpuerta, 1993, y de CHECA CrEmades, Carlos Vy la imagen del béroe en el Renacimiento, Madrid, Taurus, 1987; sobre el siglo XVII es fundamental la ya mencionada de Brown y Elliott; y para el XVIII pueden señalarse las obras de BOTTINEAU, Y., El arte cortesano en la España de Felipe V, (1700-1746), Madrid, Fundación Universitaria española, 1986, y Les Bourbons dEspagne, 1700-1808, Paris, Fayard, 1993, y el trabajo de MORAN, M., La imagen del rey. Felipe $V$ y el arte, Madrid, Netea, 1990.

8 La literatura es también un medio perfecto para ensalzar al poder. Ya se trate de la literatura política, la emblemática o el teatro. Sobre este tema son de provecho, entre ottos, YOUNG, R.A., La figura del rey y la institución real en la comedia lopesca, Madrid, Porrúa, 1979, y BERMEJo CABRERO, J. L., Máximas, principios y simbolos politicos, Madrid, Centro de Estudios Constitucionales, 1986.

9 Un ejemplo sobre la imagen que a través de la fiesta se da del poder real en Monteagudo ROBLEDO, M. P., La monarquia ideal. Imágenes de la realeza en la Valencia moderna, Valencia, Univetsidad de Valencia, 1995, y LóPEZ, R. J., Ceremonia y poder a finales del Antiguo Régimen. Galicia $1700-$ 1833, Santiago de Compostela, Universidad, 1995.

to Me centro exclusivamente en la imagen del poder que transmite la Chancillería, aunque soy consciente de los problemas que esto plantea. Sé bien, como pone de manifiesto GIESEY en su artículo "Modèles de pouvoir dans les rites royaux en France», Annales ESC, main-juin 1986, n. $^{\circ} 3$, págs. $579-599$, que al estudiar una institución hay que tener en cuenta tanto estos elementos simbólicos como los aspectos jurídicos; también es cierto que la práctica del poder, como señala ELLIOTT, «consiste, después de todo, en algo más que la manipulación de imágenes», España y su mundo..., pág. 203; y tampoco se puede pasar por alto que «afirmar que las fiestas y celebraciones... son un elemento de control social y de propaganda, no significa que necesariamente fueran recursos infalibles e inexcusables», lo que obliga a estudiar el efecto real que tuvieron sobre la población, LóPEZ, R. J., Ceremonia y poder, pág. 216 y sigs. Pero tales cuestiones se salen de los límites de este artículo. Las abordaré en la tesis doctoral sobre la Chancillería de Granada que estoy realizando en estos momentos.

11 "Como el rey había sido por muchos años la cabeza de su audiencia y no dexó de serlo por haber cesado de asistir a ella, se le dió desde su fundación, y se le ha continuado después, el tratamiento con que entonces se distinguia la misma real persona, el qual era el de Muy poderoso señor y Alteza, igual al que se le guarda al Supremo Consejo de la monarquías, SEMPERE y GUARINOS, J., Observaciones sobre el origen, establecimiento y preeminencias de las Chancillerias de Valladolid y Granada, Granada, 1796, f. 63.

Hiqpunia, LVII/ /2, núm. 199 (1998) 559-574 
Católicos-los monarcas reciben el tratamiento de Majestad ${ }^{12}$, y que las Chancillerías seguirán utilizando el título de Alteza, pero lo significativo es que en un momento determinado se las iguala al rey. Y no sólo se confieren altos honores a las Chancillerías, también a sus miembtos. Los ministros de las Chancillerías se denominan del Consejo de su Majestad ${ }^{13} \mathrm{y}$, dando un paso más, el emperador concede a los oidores un privilegio reservado a los Grandes: ser caballeros cubiertos ante el rey ${ }^{14}$. Se intenta, por tanto, prestigiar la consideración de la justicia en sí, mejor dicho, la consideración social de la justicia. Y tanta importancia tendría ésta como aquella, pues el prestigio social es clave en la España del Antiguo Régimen.

La reputación de las Chancillerías hace que los contemporáneos vean a Granada como "segunda corte», pues reside en ella «su magestuso Acuerdo de su grande Chancillería, donde nuestro grande y poderoso monarca juzgas ${ }^{15}$. Lógicamente a la Chancillería le interesa mantener esta imagen, que en gran medida coincide con la tealidad. El tribunal es, efectivamente, una «segunda corte», al custodiar el sello mayor del rey, en el que «estaba toda la autoridad real y hasta el rey mismos ${ }^{16}$. Por eso no puede tolerar que nadie, ni siquiera un

12 Sobre la cuestión, véase MARAVALI, J.A., Estado Moderno y mentalidad social (siglos XV a XVTIJ, Madrid, Revista de Occidente, 1972, t. I, págs. 254-257.

13 «Lo mismo es decir consejeros del Rey, que entenderse por hombres en quienes resplandece el amor a la religión y deseos de administrar justicia entre los particulares, como de promover el beneficio del rey y bien común de los pueblos; y por unos hombres dotados de prudencia, integridad, literatura y desinterés; y dignos a la verdad del mayor honor y respeto y de que sus preceptos sean obedecidos por todos los del reino". Escribe en términos generales GUARDIOLA y SÁEZ, L., El corregidor peffecto y juez exactamente dotado de las calidades necesarias y convententes para el buen gobierno económico y politico de los pubblos y la más recta administración de justicia en ellos, Madrid, 1785 , págs. 42 y ss.

14 Cuenta ANTOLínEZ DE BURgos en la Historia de Valladolid, que Carlos V, durante su estancia en esta ciudad en 1518, fue a la Chancilletía pata ver la forma en que se impartía justicia y «entrando el rey en la sala con la Infanta [doña Leonor], demás caballeros y señores que le acompañaban, el rey y su hermana y damas se sentaron; y el rey mandó a los oidores que se cubriesen", SEMPERE, Observaciones..., f. 63.

15 HENRÍQUeZ DE JORQUERA, F, Anales de Granada. Descripción del Reino y ciudad de Granada. Crónica de la Reconquista (1482-1492). Sucesos de los años 1588 a 1646, Granada, 1934 (ed. facsimil. Granada, Universidad de Granada, 1987), p. 12. De la misma opinión es BERMúdEZ DE PEDRAZA. En sus Antigüedades y excelencias de Granada escribe: "Con esta chancillería conservó Granada el título y majestad de ser corte», Granada, 1608 (ed. facsímil. Granada, Universidad de Granada, 1981), f. 140 v.

16 Por ello Ias Chancillerías «disfrutan la condición y reciben el nombre de curia o corte regia, y están situadas a la altura de los órganos que rodean inmediatamente al reyn, GARRIGA, C., La Audiencia y las Chancillerias castellanas (1371-1525), Madrid, Centro de Estudios Constitucionales, 1994, pág. 229. No pienso, como es obvio, que Valladolid y Granada fuesen Cortes del mismo modo que lo era Madrid desde 1561, pero sí es importante tener en cuenta este aspecto para enmarcar, entre otras cuestiones, el imaginario que rodea a la institución. De este tema se ha ocupado también CLAVERo en el estudio preliminar a las Ordenanzas de la Real Audiencia de Sevilla, Sevilla, 1995, en especial las págs. 9-25.

Hispantu, LVIII/2, núm 199 (1998) 559-574 
noble, se comporte sin el respeto debido, como no podía tolerarlo el propio rey. Su actitud frente al marqués de Salar es clarísima.

Éste visitó la Chancillería mientras se estaba celebrando audiencia pública. El marqués no se descubrió y el presidente le ordenó que lo hiciera. «A la segunda amonestación que para ello le hizo el presidente, contestó era caballero cubierto ante S.M. el rey, objetándole aquél: "marqués, si el rey os concedió tal privilegio en su corte, no pudo hacerlo en su tribunal de justicia, y yo, en representación del augusto soberano, no toleraré aquí que ningún caballero se cubra cuando se celebra tan sagrado acto. Salid o descubríos". Hizo lo propio el marqués y a los pocos días le fue comunicada una disposición del presidente, imponiéndole una fuerte multas ${ }^{17}$. Aquél apeló a Felipe II, quien le contesta: «ciertamente que eres caballero cubierto ante mí, pero no ante la justicia que alli representan mis oidores. Conque paga la multas ${ }^{18}$. El rey Prudente confir$\mathrm{ma}$, sin ninguna objeción, la disposición del presidente frente a un noble. El hecho no necesita ningún comentario.

La Chancillería es, por tanto, una institución extraordinariamente prestigiada. Para afianzar aún más su imagen mayestática, pues sabe que detrás de esta imagen está en juego el poder, y no ya el suyo, sino el de la Corona, la Chancilleria de Granada utiliza distintos elementos, que toma de la propia monarquía: el programa iconográfico del edificio ${ }^{19}$, la majestad desplegada en sus apariciones como cuerpo o la ceremonia con la que todos deben tratar al presidente.

En el programa iconográfico del edificio de la Chancillería -cuya construcción hay que verla dentro de un plan por hacer de Granada el centro ideológico del nuevo Estado castellano ${ }^{20}$ - están representadas tanto la Corona como la idea de una justicia adornada de todas las virtudes posibles. En la fachada ambas se simbolizan a través de la cartela, del escudo real y de las figuras de la justicia y la fortaleza. En la cartela, sujeta por un león ${ }^{21}$, se lee: «para que la majestad de este tribunal correspondiese a los importantes asuntos que en él se tratan, la sabiduria de Felipe II determinó engrandecer y adornar con todo

17 GARCía SAMOS, A., La Audiencia de Granada desde su fundación basta el íltimo pasado siglo. Reseña bistórico descriptiva, Granada, 1889, pág. 10.

18 Gallego y BURiN, A., Granada. Guia artistica e bistótica de la ciudad, Granada, Fundación Rodríguez Acosta, 1988, pág. 333. Es dificil creer que Felipe II llegara a utilizar un estilo tan coloquial, pero el contenido de la respuesta es suficientemente significativo.

19 No debe olvidar el historiador, y en concreto el historiador de las instituciones, el estudio iconográfico, pues es clave para aprehender «los significados intrínsecos» del objeto de análisis», PANOFSKI, E., Estudios sobre iconología, Madrid, Alianza, pág. 24.

20 BIGET, J. L., HERVÉ, J. C y THÉBERT, Y., «Expressions iconographiques et monumentales du pouvoir d'État en France et en Espagne à la fin du Moyen Âge: l'exemple d'Albi et de Grenade), en AA.VV., Culture et idéologie dans la genése de / 宅tat Moderne, Rome, École française de Rome, 1985, págs. 245-279. En especial las págs. 264-279.

21 unimal emblemático de la realeza y, por ende, asociado a la justicia divina desde época medievaly, LEÓN COLOMA, M. A., El programa iconográfico de la Real Chancillería de Granada, Granada, Fundación Rodriguez Acosta, 1988, pág. 31. Además, el león, bien se conoce, es el símbolo de la Casa de Austria. 
decoro esta tegia estanciay ${ }^{22}$. Si alzamos la vista vemos la majestad simbolizada en el escudo real, flanqueado por las imágenes de la justicia y la fortaleza. A un lado aparece Astrea con sus atributos, la espada y la balanza 23 ; al otro la fortaleza, virtud estrechamente ligada a la justicia, pues ula vara del juez lo ha de ser de manera que no la tuerça ni codicia ni temons ${ }^{24}$. La fachada cumple su objetivo. Transmite al que la contempla respeto, incluso reverencia, a la Corona y a la justicia.

Cuenta Guzmán de Alfarache «que un labrador en Granada solicitaba por su interese un pleito en voz del concejo contra el señor de su pueblo, pareciéndole que lo había con Pero Crespo, el alcalde dél, y que pudiera traer a los oidores de la oreja. Y estando un día en la Plaza Nueva, mirando la portada de la Chancillería, que es uno de los más famosos edificios en su tanto de todos los de España y a quien de los de su manera no se le conoce igual en estos tiempos, vio que las armas reales tenían en el remate a los dos lados la Justicia y la Fortaleza. Preguntándole otro labrador de su tierra qué hacía, por qué no entraba a solicitar su negocio, le respondió: "Estoy considerando que estas cosas no son para mí, y de buena gana me fuera para mi casa; porque en ésta tiene tan alta la justicia que no se deja sobajar, ni sé si la podré alcanzar"» ${ }^{25}$.

El programa iconográfico de la fachada se repite en el interior del edificio. Esculpidas vuelven a aparecer la fortaleza y la justicia, que en alguna ocasión se representa con los ojos vendados ${ }^{26}$, junto a las otras dos virtudes cardinales ${ }^{27}$ : la prudencia, la virtud política por excelencia ${ }^{28}$, y la templanza, otro de los atributos esenciales al buen gobierno y a la propia justicia. Se reitera también la representación del león y se encuentran por doquier los escudos y ar-

22 LAfuente ALCÁNTARA, M., Historia de Granada, Granada, 1843 (ed. facsimil, Granada, Universidad de Granada, 1992), t. IV, pág. 262.

23 «No ha de inclinarse la justicia nunca, siempre ha de estar en fieb), VALDECEBRO, F, Gobierno general y político sacado de las más nobles y castizas aves, Madrid, 1669, f. 89.

24 VILLAVA, F., Empresas espirituales y morales en que se finge que diferentes supuestos las traen al modo extranjero, representando el pensamiento en que más pueden ser̃alarse, asi en virtud como en vicio a la cristiana piedad, Baeza, 1613, 1." parte, f. $55 \mathrm{v}$.

25 MATEO AlEMÁN, Gužmán de Alfarache, Madrid, Cátedra, 1992, vol. I, págs. 138-139. La actitud de respeto no puede ser más clara.

26 «No ha de tener manos la justicia para recibir, ni ojos para ver su sangre, o familiares, o amigos, que sentenciarán el amor, o el odio, o el dinero, y no la verdad», VALDECEBRO, F., Gobierno general..., f. 89.

27 La representación de la justicia asociada a las virtudes cardinales tiene una larga tradición. Sobre este tema, véase GOMBRICH, E. H., Imágenes simbblicas. Estudios sobre el arte del Renacimiento, Madrid, Alianza, 1983, pág. 183 y sigs.

28 «A las demás virtudes de que debe estar adornado un príncipe ha de añadirse la prudencia, luz que alumbra todos vuestros pasos en la senda de la vida. Es la prudencia cierta prenda del ánimo en virtud de la cual mirando a todas partes, por la memoria de lo pasado, disponemos lo presente y prevenimos lo futuro, por lo que está ya claro y manifiesto tasgamos el velo de lo que está aún oculto y misterioson, MARIANA, J., Del rey y de la Institución Redl, Madrid, B.A.E., 1950, t. XXXI, pág. 565.

Hipania, LVIII/2, núm. 199 (1998) 559-574 
mas reales ${ }^{29}$. De nuevo la Corona y una justicia que "contiene en sí todas las virtudes» ${ }^{30}$. La decoración de las salas realza aún más estas imágenes.

Las salas de la Chancillería están llenas de doseles y cortinas, de objetos de plata, de almohadones y de un sinfín de adornos que no pasan inadvertidos al visitante ${ }^{31}$. La que quizá sea la sala más emblemática de la Chancillería ${ }^{32}$, la del Real Acuerdo, sintetiza perfectamente la imagen de la justicia real, que hasta cierto punto no es otra cosa que la justicia divina. Junto al dosel real, que da «no sé que dignidad que lo cubre todo y se lleva tras de sí todo el respeto» ${ }^{33}$, aparece un dosel blanco, y en medio la imagen del Crucificado. Las armas reales, al lado de Cristo. No es casual, pues los jueces «están puestos, no sólo en lugar de los reyes, sino en lugar de Dios» ${ }^{34}$.

Los jueces representan a la Corona, al poder, al rey, a Dios; por ello la imagen no puede descuidarse. Su aspecto se tiene que acomodar a la gravedad de su oficio, incluso en el vestido. No ha de quedar ninguna duda sobre su autoridad. En 1581 escribe Felipe II al presidente del Consejo: «Dias ha que he mirado en la mudanza que han hecho los de mi Consejo Real y de los otros mis Consejos, cancillerías y audiencias de las ropas largas que solían traer, y el tiempo ha mostrado la indecencia que esto ha sido, habiéndose en esto hecho en la apariencia y demostración iguales a los otros hombres que las han de respetar, con que vienen a no ser conoscidos muchos dellos en las calles y otros lugares, $y$ a perdérseles el respeto que se les debe, y hay en esto muchos otros inconvenientes, con que paresce no estar en su lugar la autoridad de los oficios». El rey manda que vuelvan a usar la ropas talares, «considerando por muy conveniente y necesario a vuestra auctoridad, para así como el oficio en que me servís es tan grave, lo sea también el hábito que debéis traer como solíades») ${ }^{35}$.

El hábito y las manetas de los jueces tienen que acomodarse a la gravedad de su oficio, y también, cuando llegue la ocasión, al dolor del príncipe en cuyo lugar están -igual que otros cuerpos, pero esto no interesa aquí-. Así, cuan-

29 También se representan otras virtudes, como la fe, la esperanza y la caridad; los hombre ilustres de la Antigüedad; y legisladores cristianos y paganos. Sobre este tema puede consultarse LEÓN COLOMA, M. A., El programa iconográfico....

30 VALDECEBRO, F, Gobierno general.., f. 87.

31 En 1659 Bertaut estuvo en Granada. Al viajero francés le impresionó la decoración de la Chancilleria. Escribe: uno he visto más sala hermosa y limpia que la de Granada, donde el presidente de ese consejo, que vive en la misma casa, me llevó cuando estuve alli a ver, que era una sala alta en la que habia una gran alfombra, sobre la cual habia muchos almohadones y sillas muy limpias", BERTAUT, F., Diario del viaje de España becbo en el año 1659, en la ocasión del tratado de la paz, en GARCIA MERCADAL, J, Viajes de extranjeros por España y Portugal, Madrid, Aguilat, 1959, v. II, pág. 656.

32 Tomo la descripción de las salas de un inventatio de los bienes y alhajas de la misma hecho en 1686, A.R.Ch.Gr., 321-4427-111.

33 Velázquez de ECHEVARRÍ , J., Paseos por Granada y sus contornos, Granada, 1764 (ed. facsímil. Granada, Universidad de Granada, 1993), t. II, f. 124.

34 Horozco de CovarRuBias, J., Emblemas morales, Zaragoza, 1604, libro II, f. $19 \mathrm{v}$.

35 RIBA GARCíA, C., Correspondencia privada de Felipe $\Pi$ con su secretario Mateo Vázquez, 1567 1591, Madrid, C.S.I.C., 1945, págs. 230 y 231. 
do muere Isabel de Borbón en 1644 la Chancillería ofrece un aspecto desolador: «los estrados, desaliñados del real adorno y desnudos de las armas y divisa de magestad, yacían con doseles de bayeta, cubiertos los asientos y tarimas de lo mismo; a cuyos tribunales (después de haber oído misa en su capilla, vestida suelo y paredes de paños negros) salieron los presidente, oidores, alcaldes de corte y de hijosdalgo y fiscales para dividirse a sus salas, cubiertas las cabeças y arrastrando largas faldas, y al mismo respecto letrados, relatores, escribanos de cámata, procuradores, recetores, escribanos de provincia, porteros y demás ministros, sin que ninguno de todos subiese a estrados ni obrase acto público dentro y fuera de Chancillería sin vestirse este traje, el qual no se alivió en juezes y ministros hasta pasadas las honras... Porque es muy del propósito vistiese el ministro del mismo dolor y sentimiento de el príncipes ${ }^{36}$.

El programa iconográfico de la Chancillería, la decoración de sus salas y el aspecto de los ministros son fundamentales para transmitir la imagen de la justicia a que me estoy tefiriendo. Ésta se afirma, incluso se agranda, en las apariciones públicas del Acuerdo. El mismo sale de la Chancillería en bastantes ocasiones, pero siempre se considera una umerced singular y rara" ${ }^{37}$ que el Acuerdo como cuerpo honre con su presencia cualquier acto; aunque, bien visto, quizá sea al propio Acuerdo a quien más interese esta asistencia, ya que es una ocasión única para mostrarse ante el pueblo como el más alto representante de la Corona, lo que sin duda contribuye a prestigiar a sus miembros.

En 1658 se celebra en Granada el nacimiento del príncipe Felipe Próspero. El 13 de diciembre el Acuerdo se dirige al convento de Gracia ${ }^{38}$. Describe el cronista «la magestad con que el Real Acuerdo salió a caballo a las nueve de la mañana», y señala el «mucho consuelo [que] dio a la ciudad toda el ver junta tanta grandeza, que como no siempre se ve el Real Acuerdo en esta forma, causó en unos y otros igual gusto [y] plazer, que es gran dicha suya tener en tanto superior [roto] ministro segura la defensa de sus agravios" ${ }^{39}$.

36 SÁNCHEZ DE ESPEJO, A., Relación bistorial de las exequias, tumulas y pompa funeral que el arzobispo, deán y cabildo de la Santay metropolitana Iglesia, corregidor y ciudad bicieron en las honras de la reina, nuestra señora Isabel de Borbón, en diez las de la Santa iglesiay en 14 de dictembre las de la ciudad, Año de 1644 ,ff. 18 v y 19.

37 Así se califica su asistencia a las fiestas por la beatificación de San Ignacio. Visitaron los ministros el claustro del convento de San Ignacio, y lo hicieron «muy despacio, para que en la sustancia y en el modo fuera calificado el favor y la merceds, De la fresta que en la beatificación del B.P. San Ignacio, fundador de la Compania de Jesús, bizo su colggio de la ciudad de Granada en 14 de jebrero de 1610 , Granada, 1610 , ff. $2 \mathrm{v}, 3$ y 45.

38 Por R.C. de 25 de agosto de 1636 Felipe IV acepta el patronazgo de la capilla, bóveda y enterramientos del convento de Gracia, que cen su nombre» conservará el Real Acuerdo. Es significativo que la primera condición de las capitulaciones firmadas entre dicho convento y el Real Acuerdo sea «que en el testero y frontispicio de la dicha iglesia y pórtico se hayan de poner dos escudos de armas reales, y otros dos en los colaterales del Altar Mayor, como y en la forma que al Real Acuerdo le parecieren, A.H.P.Gr., 201-5.151-6.

39 MaLleA, S., Granado festiva en el real nacimiento del serenisimo principe don Felipe Próspero, Granada, 1658 , ff. $7 \mathrm{v}$ y sigs.

Hippunia, LVIII/2, núm. 199 (1998) 559-574 
La aparición pública del Acuetdo siempre causa en el pueblo el mismo efecto. Además, se le recibe con los máximos honores y ocupa un lugar preferente en todas las ceremonia a las que acude, lo que en ocasiones provoca enfrentamientos con el resto de autoridades locales. Disputas lógicas, pues, no nos engañemos, la cuestión protocolaria, con ser importante, es sólo un pretexto; realmente las origina la lucha por el poder. No voy a analizar estos enfrentamientos. Ahora sólo me interesa señalar cómo aprovecha la institución, si no más poderosa -cuestión que hay que dilucidar en cada momento-, sí más prestigiada de la ciudad, sus apariciones públicas para reforzar aún más su identificación con la Corona y para reafirmar de este modo su poder.

Las fuentes señalan en muchas ocasiones la presencia en las fiestas de toros $\mathrm{y}$ en las de cañas de tan «apostólicos y regios magistrados» ${ }^{40}$. Es lógico, pues el Acuerdo preside todas las fiestas reales celebradas en Birrambla ${ }^{41}$, donde se le reserva un balcón. Hacia allí se dirigia "como quando va a las honras de los reyes en sus coches y entrando en la plaça de Bibatrambla pasan por debajo [de] los balcones de la ciudad. $Y$ el corregidor, alcaldes mayores, $y$ veintiquatros $y$ jurados están en pie, descubiertos, y como va pasando el Acuerdo les va haciendo cortesía por las ventanas de los coches que caen a aquella parte, y en particular el señor presidente, alargándose para que le vean, y así llega, volviendo la cortesía, al marqués de Mondéxar, que es alcayde de la Alhambra, fortaleza de la ciudad, y a los demás caballeros y señores que están en aquella acera, y se apean junto a la pescadería donde ven las fiestas, $y$ todos se ponen a uno y otro lado del corredor hasta que ha pasado el señor presidente y toma su silla, que es de terciopelo morado. $Y$ en la ventana está puesto su sitial del mismo terciopelo y dos almohadas con borlas de oro y cubierto con un tafetán morado que quitan quando se sienta, y debajo está un dosel o escudo bordado con las armas reales, que cae a la plaçàs ${ }^{42}$.

El Acuerdo, consciente de la importancia que tiene ocupar el balcón principal de esta plaza y recibir a su llegada el «homenaje» de las distintas autoridades, no quiere renunciar a este privilegio. Cuando en 1773 se construye la plaza de toros de la Real Maestranza uno de los fiscales de la Chancillería pide que se realice un informe que indique si el balcón que ha de ocupar la Chancillería «tiene, en sí mismo y en relación con las demás partes de la plaza, el decoro y

40 BIGIL, F., Elogio a la ciudad de Granada, en que se refieren las festas reales que celebró en 12 y 15 días del mes de entero deste año de 1630 por el feliz nacimiento del principe de España, Granada, 1630, s.f.

41 "Quando la ciudad de Granada acuerda que haya fiestas que llaman teales de toros y cañas y otros regoçijos que se hacen en la plaça de Bibartambla, antes de publicarlas con trompetas y atabales como se acostumbra, envía un caballero veinte y quatro y un jurado a dar quenta dello al señor presidente y después, en el acuerdo inmediato a las fiestas, vienen el caballero veinte y quatro y jurado comisarios dellas por la ciudad a convidar al acuerdo para ellas y se les da asiento en un banco de nogal, $y$ hace la embajada el veinte y quatro, $y$ le responde el presidente que el acuerdo irás, Práctica de la shancilleria de Granada, B.N., Ms. 309, f. 588 v.

42 Ibid, ff. 588 v y 589. 
dignidad que corresponde a los señores ministros» ${ }^{43}$. La Chancillería no quiere, ni puede, aparecer sin la dignidad debida.

En las ceremonias religiosas el presidente y oidores se sitúan "al lado del Evangeliom. Así sucede en todas los actos celebrados en la Capilla Real ${ }^{44}$, en las exequias realizadas en la Catedtal por la muerte de la reina Isabel de Borbón 45 y también en algunas fiestas particulares, como la que organizan en 1747 los padres agustinos con motivo de la canonización de San Fidel de Sigmaringa y de San José de Leonisa, donde «todo lo adornaron altar, púlpito y Acuerdo» 4. Éste, pues, ocupa en todas las ocasiones en la Iglesia un lugar que corresponde al tey. La razón es obvia: «representa su real persona, autoridad y poden» ${ }^{47}$.

En 1610 la Compañía de Jesús festeja la beatificación de San Ignacio. «Los asientos del Acuerdo se pusieron en medio de la capilla, el sitial de terciopelo morado del señor presidente... y a un lado y a otro, en los asientos del Acuerdo, los señores déb) ${ }^{48}$. Se adornaron con profusión la capilla mayor y la tarima desde la que el obispo de Jaén iba a oficiar la ceremonia, pero por la autoridad udel Acuerdo, que había de estar presente, no se pudo poner dosebs. El dosel, símbolo áulico por excelencia, no puede cubrir a un ministro de la Iglesia, pues están presentes los ministros de justicia que representan al propio monarca.

La identificación del Acuerdo con la Corona es clarisima. La proclamación en Granada de Luis I en 1724 no deja la menor duda. Durante el acto, como era habitual, los comisarios se ditigen a la Plaza Nueva - sede de la Chancillería - para tremolar el pendón ${ }^{49}$, y lo hicieron, por cortesía, "con los sombreros en la mano, al más verdadero trasumpto de la más viva imagen de nuestro nuevo rey, al tribunal más grande, a quienes tributa sus veneraciones nuestro respeto, al Real Acuerdo de esta Chancillería, representado en los señores presidente, oidores y demás togados ministros que lo componen; en cuya alabança, nada podrá decir mi insuficiencia, que no sea agravio de su soberanías ${ }^{50}$.

43 A.R.Ch.Gr., 321-4.369-8.

44 Henriquez de Jorquera, F., Anales..., pág. 63.

45 SÁNCHEZ DE ESPEjO, A., Relación bistorial de exequias..., f, $35 \mathrm{v}$.

46 Relación muy entretenida y curioso romance, en donde verá el currioso lector las plausibles fiestas y rendidos cultos con que en expresivas demostraciones de su cariño, celebró la muy inclita ciudad de Granada con sus regios tribunales, ilustrisimos cabildos y sapientisimas comunidades a los dos béroes del mundo y luces de la Iglesia, San Fidel de Sigmaringa y San José de Leonisa, en este presente año de 1747, s.f.

47 ANTOLINEZ DE BURGOS, Justino, Historia eclesiástica de Granada, Granada, 1611 (Granada, Universidad de Granada, 1996), pág. 462.

${ }_{48}$ De las fiestas que en la beatificación..., ff. 21 y $21 \mathrm{v}$

49 "Quando se levanta el pendón real en la sucesión de nuevo tey la Chancillería no tiene lugar en el acto y paseo con la ciudad. Y lo que se hace es que si pareçe convenir autoriçe el acto la Chancillería salen los señores presidente y oidores y demás ministros superiores en forma de Acuerdo y se van derechamente al tablado al tiempo que llega la ciudad, y levantado el pendón se vuelve el Acuerdo y la ciudad prosigue su acton, Práctica..., f. 577.

50 Relación de las plausibles aclamaciones y públicas ceremonias con que esta muy noble, muy leal, nombrada y gran ciudad de Granada, solemnizó la de levantar el pendón por el rey nuestro señor, don Luis I, Granada, 1724, pág. 14.

Hispania, LVIII/2, núm. 199 (1998) 559-574 
El Acuerdo es «el más verdadero tramsupto de la más viva imagen de nuestro reyn, y el presidente de la Chancillería no es otra cosa que el alter ego de Su Majestad. Así lo ven sus contemporáneos, quienes lo comparan con el sol -uno de los símbolos más característicos de la realeza- ${ }^{51}$, y como tal se comporta él mismo.

El 6 de julio de 1658 se celebran totos en Birrambla a los que acude el Acuerdo. «A recibirlo salieron a la puerta del Zacatín los caballeros comisarios, que ufanos recibieron desde la primera hasta la última deidad soberana por fiestas tan prevenidas. En onze coches con orden concertado señoreó la plaza, representando en el acompañamiento autorizado que llevaba la grandeza majestuosa que contenía. En el último y dorado coche, que pudiera ser del sol en lo hermoso y rico... iba el dignísimo presidente, a quien esta ciudad daba lo que reconocida confiesa. Acompañábanle los quatro magistrados más antiguos, viéndose como el sol, presidente de tan luziente estrellas ${ }^{52}$.

El presidente está muy por encima de los demás miembros del Acuerdo. Su estricta jerarquía no deja lugar a dudas. Ya sea en las salas, en la forma en que le tratan los ministros, o en sus apariciones públicas - como hemos visto-, siempre queda clato que ninguno de sus "compañeros», ni siquiera el oidor más antiguo cuando hace oficio de presidente ${ }^{53}$, se le puede igualar. Podría citar muchos ejemplos, pero hay uno especialmente significativo: cuando el Acuerdo acoge bajo su patronazgo el convento de Gracia se especifica que la «bóveda que está debajo de la capilla del altar mayor sea entierto o depósito para los señores presidentes... y la bóveda que está debajo de la capilla mayor sea entierro o depósito para los señores oidores, alcaldes del crimen, alcaldes de hijosdalgo y fiscales y alguacil mayor de la dicha Chancillerías ${ }^{54}$. Incluso muerto, el presidente es la cabezá del ureal senado».

La entrada de los presidentes en Granada se conviette en una fiesta que se celebra en distintos lugares del reino ${ }^{55}$. Refiriendo su entrada en Granada, escribe el presidente Velasco: «fue con la pompa, acompañamiento y ceremonias que se practican en iguales casos. $\mathrm{Y}$ así mismo con repetidas salvas de artillería y mosquetería de la puerta de Elvira y real fortaleza de la Alhambra y de la tropa que estaba sobre las armas en la Plaza Nueva, al frente de este magnífico

51 Felipe II es el primer monarca que se identifica con el Sol. La adscripción de esta divinidad mayor a la monarquía será constante en la tradición hispánica, Gállego, J., Visión y simboLos..., pág. 47.

52 MALlEA, S., Granada festiva..., f. 15 v.

53 En estas ocasiones el oidor más antiguo no puede aparecer con los atributos propios del presidente, sporque un oidor, respecto de los oficios, no ha de ser de ygual preeminencias. En los actos que preside en el convento de Gracia no se le pone, como al presidente, un "sitial que es alto y cubierto con un paño morado... al señor oidor más antiguo sólo se le pone silla sobre un tapete y una almohada sin cubierta», Práctica..., ff. 598 y 598 v.

54 A.H.P.G., 201-5.151-6.

55 Asi, por ejemplo, en 1662 se corren toros en Baeza cuando se nombra presidente a don Lope de los Ríos, CRUZ CABRERA, P., Patrimonio arquitectónico y urbano en Baeza: siglos XVXVIIL. Aristocracia urbana y conmemoración pública, Granada, 1994. Tesis doctoral inédita, pág. 48.

Hispania, LVIII/2, ním. 199 (1998) 559-574 
edificio de la Chancillerias. La presenciaron «la comitiva y el innumerable concurso de gentes, que por casualidad se hallaban apostadas en la carrera, y especialmente en el espacioso campo de Nuestra Señora del Triunfo contiguo a la referida puerta. Siguióse a la toma de posesión el abundante refresco, que estaba preparado para todos los compañeros, y las señoras recibidoras de mi mujens ${ }^{56}$.

La ceremonia de entrada es clave. No entra un hombre, entra el presidente de la Chancillería, el máximo representante de la Corona. Llega a Granada el poder real por excelencia. En 1773 se introducen novedades en esta ceremonia para disminuir el egtavamens económico que supone. El conde de Aranda aprueba esta medida, pero ordena que «a fin de que no decaiga la idea que deben tener los naturales de la autoridad judicial, harán los presidentes su entrada formal en público, la ciudad su homenaje y los cuerpos que la precedens ${ }^{57}$ igualmente.

$\mathrm{Al}$ presidente se le recibe "con toda la pompa y majestad posible» ${ }^{58}$, y durante su estancia en Granada procura que esta majestad no decaiga un ápice; para ello mantiene un rígido protocolo. «No se presenta al público separado del cuerpo del tribunal sino en tres ocasiones... [y] le está prohibido hacer visitas y asistir a concurrencias particulares, y así no las paga a los grandes de España y otras personas del mayor carácter que se les presentany ${ }^{59}$.

El presidente no puede aparecer en público solo, como un hombre, tiene que aparecer como la primera personalidad de la monarquía en el territorio jurisdiccional de la Chancillería, como la cabeza del Real Acuerdo. Tampoco puede visitar a nadie, $y$, cuando lo hace, tal visita se "disfraza» "0; sin embargo, todos han de presentarle sus respetos. Es normal que dos viajeros, Bertaut ${ }^{61}$ y Townsend, fueran a verle. Éste último, que generalmente disfrutaba de la hospitalidad del arzobispo, no duda en acudit siempre que el presidente requiere su presencia ${ }^{62}$.

\footnotetext{
56 A.R.Ch.Gr., Libro secreto del presidente Velasco, libro 197, ff. 296 y 296 v. Velasco entra en Granada el 8 de octubre de 1766, A.R.Ch.Gr., 322-4.446-13.

57 El 16 de junio de 1773, A.R.Ch.Gr., 321-4.422-14.

58 Así califica HENRÍQUEZ DE JORQUERA el recibimiento hecho al presidente Olmedilla a principios del XVII, Anales..., pág. 583.

59 A.R.Ch.Gr., 321-4.389-2.

60 Las tres ocasiones en las que el presidente se presenta en público sin ir acompañado por el Acuerdo son: durante la fiesta de la Concepción; en Semana Santa, cuando sale a ver las estaciones; y tras su llegada a Granada, "para pagar la visita del M.R. arzobispo de esta ciudad. Ésta va disfrazada con el pretexto de haber de ir a visitar el templo de Nuestra Señora de las Angustias, patrona de este pueblo». En estas ocasiones el presidente realmente no aparece solo; aunque no le acompañe el Acuerdo va rodeado de diferentes ministros, y además, estas salidas también están sujetas a un estricto ceremonial, ibid.

61 Diario del viaje..., pág. 589.

62 «En cuanto hube llegado a Granada, presenté mis cartas al arzobispo, que me recibió muy amablemente y fue bastante obsequioso para hacerme constantemente comer con él durante el tiempo de mi estancia, excepto cuando estaba invitado por don Juan Marino de la Barrera, presidente del tribunal de la Chancillerías, TOWNSEND, J., Viaje a España becho en los años 1786-1787, en García Mercadal, Viaje de extranjeros..., vol. III, pág. 1579.
}

Hïpanjo, LVIII/2, núm. 199 (1998) 559-574 
La ceremonia de las visitas le sirve al presidente para dejar claro que él ocupa el primer lugar ${ }^{63}$. Por eso no es de extrañar que el presidente Velasco ${ }^{64}$ no consienta que nadie deje de rendirle este homenaje. Ante él se presentaron en la forma debida Ricardo Wall, teniente general de los reales ejércitos y del Consejo de Estado de S.M., el marqués de Villadarias, asimismo teniente general; los generales de San Francisco, San Juan de Dios y San Francisco de Paula; y también el embajador del emperador de Marruecos. Algunos, sin embargo, incumplen esta obligación, lo que provoca la lógica reacción del presidente. Es el caso del inspector de milicias Martín Álvarez, que no le visita. Velasco pide a Aranda el 2 de agosto de 1768 que tome cartas en el asunto y resuelva «lo más conveniente a la causa pública y al honor deste tribunabs 65 .

Tampoco tolera, ni puede tolerar, Velasco, como ningún otro presidente, que nadie se dirija a él con un título inferior a su dignidad. En 1768 se cartea por cuestiones de oficio con el teniente general José Semmanat, gobernador político de Cádiz. José Semmanat trata a Velasco de Ilustrísima y éste le trata de Excelencia. Pero surge un problema cuando Semmanat en varias ocasiones le llama tan sólo Señoría. El 9 de septiembre Velasco le escribe indignado: (para que no extrañe [a] Vuestra Señoria este tratamiento, le prevengo como no hay grandes de España, cardenales, arzobispos, obispos, cabildos, ciudades, capitanes generales, gobernadores políticos o militares, y ni otras personas algunas visibles del distrito de toda esta Chancilleria, que dejen de dar a sus presidentes de palabra y por escrito el tratamiento propio que a los camaristas de Castilla. $Y$ no debiendo yo por razón alguna tenerme en menos que mis antecesores, faltaría sin duda a mí mismo, y a lo que se merece este empleo, en continuar tratando con tanta distinción a quien una y otra vez anda tan escaso conmigo sobre este particular, no obstante de ser gobernador político dentro de este referido distrito, en el qual está resuelto por repetidas reales cédulas impresas en nuestras ordenanzas que en las funciones públicas donde concurren el presidente y el capitán general de este reyno, prefiera el primero al segundom.

63 Al presidente Juan Bautista Valenzuela Velázquez, que sirvió esta plaza en la primera mitad del XVII, "quando le venia a visitar el señor marqués de Mondéjar, grande de España, alcaide perpetuo y capitán general de los alcázares reales de la Alhambra, no le cedía su silla, porque el señor presidente no la da a nadie». Y tampoco se la cedió «quando vino a Granada don Luis Gudiel y Peralta, del Consejo Supremo de su Majestad, a negocios del Real Servicion, Libro secreto..., f. 422.

64 Había sido alcalde del crimen de la Audiencia de Zaragoza (1739-11-20 - 1752-04-18), oidor de la Chancillería de Valladolid (1752-04-18 - 1760-03-05) y fiscal de la sala de Alcaldes de Casa y Corte (1760-03-05). Se le nombra presidente de la Chancillería de Granada el 6 de julio de 1766 y toma posesión el 8 de octubre del mismo año. Ocupa la presidencia hasta el 2 de mayo de 1770, cuando sale de Granada para tomar posesión como consejero del Consejo de Castilla -el nombramiento es de 1770-04-10- El 23 de octubre de 1785 pasa a la Cámara de Castilla, donde permanece hasta su muerte el 1 de agosto de 1788, A.R.Ch.Gt., 322-4.446-13, $321-4.340-9$, Libro secreta..., f. 295 y A.H.N., Consejos, libros 738 y 739.

65 Libro secreto..., ff. 416 y $416 \mathrm{v}$. 
El día 16 Semmanat se disculpa, alegando que las Guias de Forasteras no especifican este tratamiento ${ }^{66}$.

Velasco informa sobre el asunto a Aranda y le pide que «en las uiteriores Guias de forasteros sean puestos los presidentes de Chancillerías en el distintivo de camaristas de Castilla e Indias que sin violencia les corresponde, mediante tener los primeros igual graduación para el tratamiento que los presidentes de los Consejos de Indias, Ordenes y Hazienda (no grandes de España)... A cuyo efecto conspiran también otras poderosas tazones, quales son: el haber servido estos empleos obispos, atzobispos, patriarcas y aún cardenales; y ascendido a ellos no pocos consejeros de Castilla; el permitirseles dosel con los retratos reales y tomar puerta y silla en las presentaciones y visitas que reciben de prelados y grandes, sin pagarlas a nadie; el hacer de virreyes en sus respectivos distritos y el preceder los de esta Chancillería a los capitanes genetales de este reyno en las funciones públicas... Por todo lo qual espero de la notoria bondad y justificación de V.E. que no le parecerá mal ésta mi reverente súplica, que de nuevo reitero, no por rasgo alguno de vanidad, y sí únicamente mirando por el honor y decoro del empleo». ${ }^{67}$

El presidente deja claro que no es la persona la que merece todo el respeto, sino el oficio, y lucha por no perder ninguna de las prerrogativas protocolarias. Es lógico, conoce su significado ${ }^{68}$. Además, éstas sólo deben cesar ante el rey.

En 1730 Felipe V visita Granada y se aloja en la Alhambra. Se acuerda «que el señor presidente [de la Chancillería] visitase a los jefes y señores que posaban en la Alhambra, sin hacer en esto reparo, siendo persona de especial carácter y distinción, porque respecto a palacio no se podía entender quebrantada la ceremonia de la presidencia. Debía ser aquella casa excepción de esta regla. Pero en quanto a todos los demás grandes, embajadores y personas que se aposentaron en la ciudad mantuviese el señor presidente la ceremonia y estilo de la presidencia constante y firme, como si no estuviesen aquí sus majestades» ${ }^{69}$. El presidente debe presentar sus respetos, por supuesto, a los reyes (o a los que por la proximidad a éstos y por su categotía participan de alguna manera de la realeza), ya que «el delegado de un monarca despide tanto resplandor como el mismo monatca hasta que éste se presentes ${ }^{70}$.

66 Le contesta Velasco el día 23 «que no por las guías despreciables de forasteros, y sí por nuestras leyes patrias... se deben gobernat estos asuntos», ibid, ff. 308,632 y sigs.

67 Ibid, ff. 628 y $628 \mathrm{v}$.

68 «Todo lo que son ceremonias que miran lo público son las murallas que conservan lo sustancial dél. Porque de la preeminencia nace la honra y la obediencia, y della la estimación y la reputación, y desta el ser uso y exercicio del oficio, que quando se da un titulo por V.M., así como no se puede quitar sin causa legítima, tampoco sus preeminencias ni el estado que tenia quando se entró a servir, y de lo contrario resulta agravio y desautoridad del ministro desposeídon, B.N., V.E. 208/283. Estas palabras son posiblemente del presidente del Consejo de Hacienda y están escritas a principios del siglo XVII. Pero creo que tienen plena validez en estos momentos.

69 Libro secreto..., f. $423 \mathrm{v}$.

70 «Y entonces, continúa Shakespeare, todas sus grandezas desaparecen como el agua de un arroyo que va a abismarse en el vasto seno de los mares), El mercader de Venecia, Madrid, Alba, 1984, pág. 118.

Hispania, LVIII/2, ním. 199 (1998) 559-574 
Queda claro que el presidente de la Chancillería ocupa el primer lugar, incluso por delante de los consejetos de Castilla ${ }^{71}$. No podía ser de otra manera, pues, como ya he señalado a lo largo de estas páginas, la Corona dio a la Chancillería y a sus ministros un prestigio impresionante. También he indicado que el programa iconográfico del edificio, la majestad desplegada por la institución en sus apariciones como cuerpo, el ceremonial que se guarda al presidente y toda la simbología que rodea al organismo trasmiten al pueblo una cierta imagen de la justicia.

Gracias, entre otras cosas, a este lenguaje teatral, preñado de símbolos, por el que es fácil deslizarse de la imagen a la idea, pasando por los conceptos ${ }^{72}$, se difunde la noción de una justicia adornada de todas las virtudes imaginables y, sobre todo, imparcial ${ }^{73}$, que se asemeja a «la imagen de Dios, que en ella resplandeces ${ }^{74}$.

La cuestión es averiguar qué se persigue con esta representación. Es evidente que se quiere hacer presente todo el poder que emana de la justicia y afirmar, al mismo tiempo, la posición de la Chancillería en su ámbito jurisdiccional ${ }^{75}$. Pero la Chancillería es un poder delegado, un instrumento de la Corona. Es lógico que si es posible, y en este caso lo es, esta imagen se use para algo más.

La Chancillería es una de las más importantes instituciones de la monarquía. Al residir en ellas el sello, las ciudades en las que se establecen se convierten en cortes. Por tanto, una Corte (residencial y administrativa en Madrid) y dos cortes de justicia en puntos equidistantes, Valladolid y Granada. De esta manera la Corona en el aspecto que más interesa: la administración de justicia, se acerca al pueblo. Pero, al mismo tiempo, mediante la visualización del poder judicial, que también es administrativo, eleva a la Chancillería por encima de cualquier otra institución, significando la primacía de la justicia, y obliga a todos a este reconocimiento. Por lo mismo, la Corona, al potenciar visualmente el po-

71 Por una Real Cédula dada en Madrid el 30 de diciembre de 1636 se manda que squando esa Chancillería asistiere a qualquier actos públicos festivos en forma de audiencia, si acaeciere a estar en esa ciudad alguno de los del nuestro Consejo le aviséis y convidéis de vuestra parte, para que se halle en todos los dichos actos dándole silla ygual y inmediata después de la de lo presidentes o gobernadores que fueren desa audienciau, A.R.Ch.Gr., Libro de cédulas y autos acordados, libro 186, f. 29.

72 Cfr. de GÁlLEGO, J, Visión y símbolos.... En especial págs. 189 y sigs.

73 «Dios te guarde Granada, en quien Astrea| Tiene su regio tribunal Augusto| De Evandros y Lycurgos, en que vea | el litigante su derecho justo, | sin que pasión empañe (sombra sea) | El espejo a favor de caso injusto, | Pues en civiles, criminales salas, | Ni valen brazos, ni se admiten alas", ANTEQUERA y ARTEAGA, PEDRO, Excelencias de Granada expresadas en un epigrama, Granada, 1610.

14 LOPE DE VEGA, El mejor alcalde, e/ rey, Madrid, Espasa Calpe, Colección Austral, 1990, pág. 116 .

75 Éste es también el papel del ceremonial en los Parlamentos franceses, CHaLINE, O., «Les fonctions du cérémoniel au parlement de Normandie (XVIIe et XVIIIe siècles)» en POUMARÈDE, J. et ThOMAS, J., Les Parlements de Province. Potvoir, justice et société du XV au XVTIT siècle, Framespa, Toulousse, 1996, págs. 793-804. 
der de la Chancillería no hace otra cosa que potenciar su propio poder, mediante lo que $\mathrm{M}$. Weber ha llamado la rutinización del carisma ${ }^{76}$, y realzat el poder administrativo a los ojos de los dominados. Algo que, por otra parte, interesa a la propia Chancillería. De ahí la importancia de la visualización de la justicia, en el sentido que he intentado mostrar en este artículo para la Chancillería de Granada. De ahí la importancia de la visualización del poder sobre el que inciden tantos y tantos trabajos hoy en día.

76 Economia y sociedad. Esbozo de sociologia comprensiva, Madrid, Fondo de Cultura Económica, 1993, pág. 197 y sigs.

Hixpania, LVIII/2, núm 199 (1998) 559-574 